\title{
Statyba
}

\section{THE CAUSES OF SHEAR CRACKING IN PRESTRESSED CONCRETE BOX-GIRDER BRIDGES}

\section{Z. Kamaitis \& Z. Kamaitis}

To cite this article: Z. Kamaitis \& Z. Kamaitis (1996) THE CAUSES OF SHEAR CRACKING IN PRESTRESSED CONCRETE BOX-GIRDER BRIDGES, Statyba, 2:8, 26-34, DOI: 10.1080/13921525.1996.10590169

To link to this article: https://doi.org/10.1080/13921525.1996.10590169

曲 Published online: 01 Nov 2012.

Submit your article to this journal $\pi$

III Article views: 2555

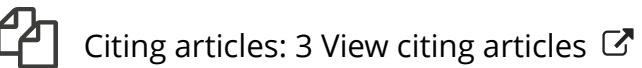




\section{THE CAUSES OF SHEAR CRACKING IN PRESTRESSED CONCRETE BOX-GIRDER BRIDGES}

\section{Z. Kamaitis}

\section{Introduction}

Bridges are considered in Civil Engineering as the most complex and important structures having a great significance for road transport system of every country. The majority of bridges constructed in Lithuania are of relatively short span with the range of 6 to $40 \mathrm{~m}$ approximately. Superstructures are composed of simply supported reinforced or prestressed $T$ - type beams or various kinds of slabs. For spans over $40 \mathrm{~m}$ continuous prestressed box cross -section beam and frame bridges are used. Posttensioned precast concrete has been used for cantilever system construction up to $100 \mathrm{~m}$.

The most obvious advantages of precast box cross-section superstructure are: high bending (for positive and negative bending moments) and torsional stiffness, maximum economy of materials, good aesthetic appearance, the possibility to use the space inside the box girder. The box cross-section reinforced concrete girders are widely used today in the world for beam, frame, arch, cable-stayed and suspension bridges. Probably the first cast-in-place box-girder continuous prestressed bridge with two spans of 62.7 m was built over the River Maas in 1948 [1]. The first precast box-girder bridge in Europe was built in France. The bridge Choisy-le-Roi over Seine has 3 spans $37.5+55+37.5 \mathrm{~m}$. The Lievre River bridge in Quebec was the first precast prestressed segmental bridge built in 1967 in North America. This was followed by segmental bridge $(30.5+61+30.5 \mathrm{~m})$ near Corpus Christ, Texas (US) in 1973 [2]. The first and the longest span (with centre span of $100 \mathrm{~m}$ ) precast segmental bridge in Lithuania over the River Neris in Vilnius was completed in 1969.

In recent years, in many concrete bridges intensive deterioration or damage was observed. Dramatic failures of bridges in use have brought attention to the problem facing the ageing bridges in many countries [3]. Our analysis of defects in reinforced concrete and prestressed concrete bridge structures in Lithuania [4] shows that the main damages are due to concrete cracking, deterioration of concrete, and reinforcement corrosion. Structural damages are caused by design errors, poor workmanship and maintenance, aggressiveness of environment.

Any overloaded reinforced concrete structure can fail mainly in flexural or shear mode. Design flexural failure is most preferable because it proceeds by excessive cracking and deflections, giving ample warning of collapse. Shear failure in most cases can be of a brittle type and gives little warning of imminent collapse. The failures of structures in shear resulted primarily from the formation of shear cracks which are inclined approximately at an angle of 30-60 degrees to the longitudinal axis of the beams. Concrete cracking is a widespread defect in concrete structures. In many post-tensioned bridges and viaducts built until 1980 in Lithuania as well as in the former USSR [5], an intensive shear cracking of box girders was observed. Due to concrete cracking the risk of bond or fatigue failure as well as the corrosion of reinforcement occur. Cracks also change the behaviour of the original monolithic structure under loading. It should be noted that cracks are not totally avoidable in prestressed concrete structures, but their presence destroy the integrity of the structure and influence the serviceability and sometimes carrying capacity of the structure. Therefore, it is very important to know how to determine the structural significance of a crack and its effect on the serviceability or ultimate limit state of the structure. 
In this article the shear cracking and its causes for box-girder or frame post-tensioned segmental prestressed concrete bridges are analysed.

\section{Shear cracking of girders}

Intensive shear cracking in the box-girder webs is observed in many prestressed concrete bridges and viaducts. Shear cracks normally manifest themselves in a zone near supports, close to midspan or at locations between. They are inclined at approximately a 45 degree angle. The shear cracks usually occur near the centroidal axis and extend to the junction of the web and the upper and lower slabs. The typical examples of shear cracking are shown in Fig. 1 and 2.

Special inspections of the bridges were made in order to study and evaluate the long-term cracking process in structures. Two kinds of shear cracking mechanism can be mentioned. In the Gelezinis Vilkas 2bridge over the Neris River, for example, only one diagonal crack in the box girder was found in the fullscale acceptance load testing (Fig. 2, a). Under service loads the crack increased both in width and length. New single diagonal cracks in both webs of opposite girder appeared with time. During the last special inspection it was found that cracks had opened up to $1 \mathrm{~mm}$ width or even more. The diagonal tension cracks developed toward the top and bottom slabs of the beams and crossed the concrete web width at the juncture of the webs with bottom and top slabs, separating the slabs from the webs. The splitting horizontal cracks continue to grow along the bottom level of the upper slabs. The shapes of .the cracks suggest that high shear force as well as the negative moments at this section influenced the formation and development of these cracks.

In other bridges the girders show extensive diagonal web cracking (Fig. 2, b). The length and width of the main inclined cracks in the webs during a certain period of time remain unchanged or sometimes begin to decrease. Furthermore, new inclined cracks begin to appear (Fig. 3, a). The process of cracking should be reported not only by maximum width of cracks but also by intensity parameter of cracking:

$$
I=\Sigma a_{c r} l_{c r} / A,
$$

where $a_{c r}$ and $l_{c r}$ are width and length of a particular crack, respectively; $A$ - total area of cracked surface of the element.

From Fig. 3, a and b it can be seen that in spite of stabilisation of maximum crack width, the process of cracking continue to proceed with time. This analysis led us to the conclusion that the strengthening of the structure became an absolute necessity.

Two web-shear different cracking mode seems to be closely related to the web reinforcement. The principal inclined crack appears and propagates rapidly in beams with insufficient amount of web reinforcement. Where the effective stirrups were provided to control concrete cracking, many fine cracks appear. The location of the cracks in box girders is influenced by such factors as the loading conditions, the cross-section parameters, and stressstrain gradient.

The consequences of observed cracking in the bridge structures can be estimated as follows:

* serious reduction of the strength and safety margin, which can lead to the failure of single element or a bridge deck as a whole;

* progressive reduction of the stiffness of the structure leading to an increase in deformations and redistribution of internal forces;

* future reduction of safety of the structures due to corrosion of reinforcement crossing the cracks;

* reduction of serviceability of the bridge due to poor circulation quality or increased vibration of structures and as a result the necessity of weight or speed limitation of vehicles;

* bad aesthetic appearance.

The cracking of the structure as shown in Fig. 2, a leads to the detachment of parts of the box girders, reduce the compressive zone of cross-section, the carrying capacity, and the rigidity of the beams. 

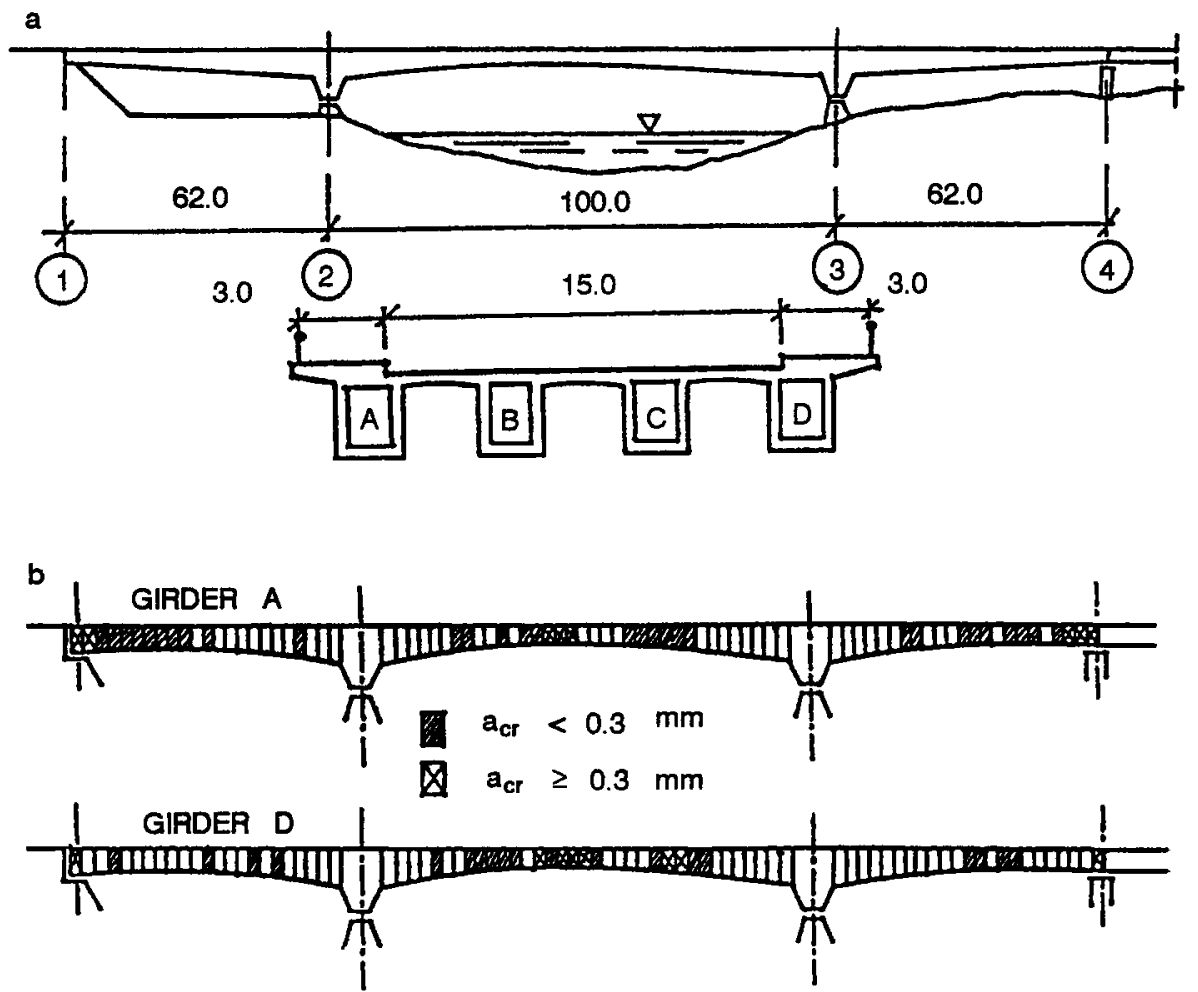

Fig. 1. Bridge over the Neris River in Vilnius; a - bridge elevation and cross section; $b$ - web shear cracking in box girders $A$ and $D$
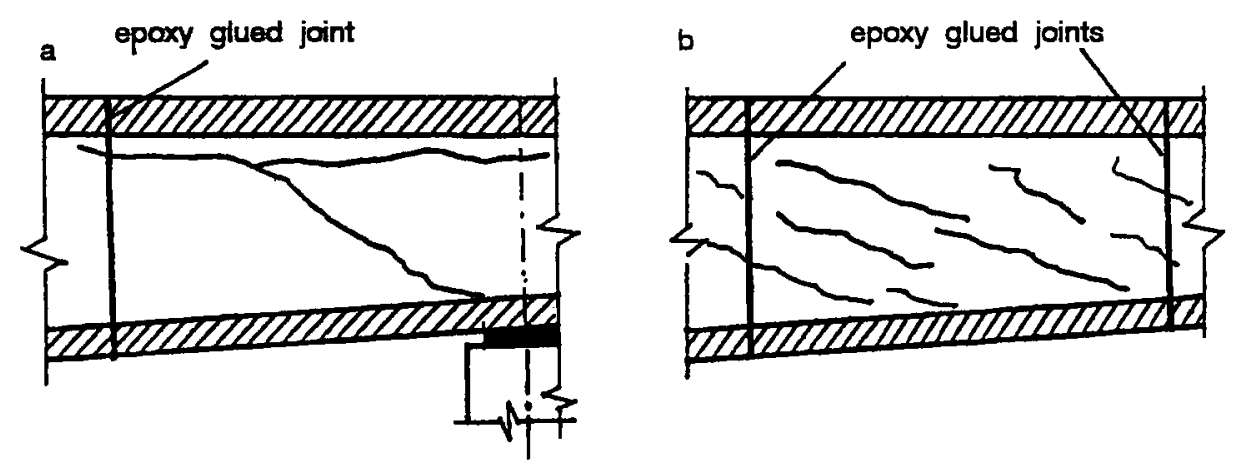

Fig. 2. Two modes of web cracking for segment of box girders
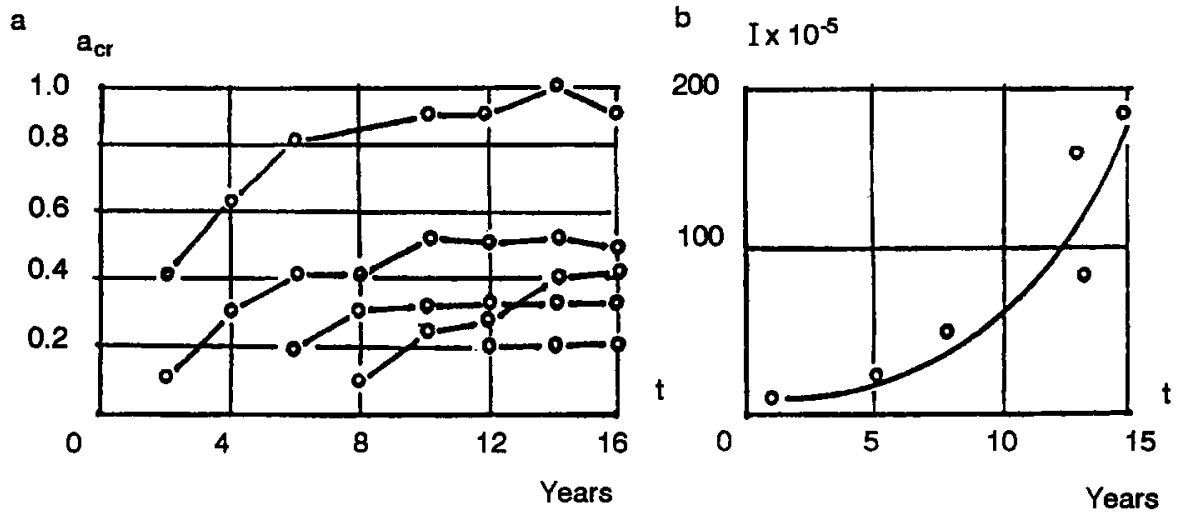

Fig. 3. Crack width (a) and intensity parameter of web cracking (b) versus time 
In cracked reinforced concrete, corrosion of the reinforcement and freeze-thaw deterioration of the concrete takes place. It is assumed that wider cracks would give easier access to aggressive substances. The width of cracks in the reinforced concrete must be controlled as a function of environmental aggressiveness. Different codes prescribe limiting crack widths. For ordinary reinforced concrete bridge structures this limit is of $0.2 \mathrm{~mm}$. For prestressed concrete bridge structures no shear cracking is allowed.

Visual acceptance of the structure from the point of view of aesthetic appearance depends on bridge owner's requirements or public opinion. Location of a bridge is an important factor of the aesthetic prestige of the structure.

\section{Causes of cracking}

Cracking is an important limit state to be considered in the design of prestressed concrete structures. Different codes give different methods for the evaluation of cracking resistance. The bridges in question built in Lithuania were designed to meet the SN 365-67 requirements for the $\mathrm{H}-30$ and AK-80 loading. Diagonal cracking resistance related to the normal and vertical stresses $\sigma_{x}$ and $\sigma_{y}$ and the shear stress $\tau$ can be predicted by calculating the maximum principal tensile stress as

$1 / 2\left(\sigma_{\mathrm{x}}+\sigma_{\mathrm{y}}\right)-1 / 2\left[\left(\sigma_{\mathrm{x}}-\sigma_{\mathrm{y}}\right)^{2}+4 \tau^{2}\right]^{1 / 2} \leq k R_{b, \text { sen }}$

where $R_{b t}$ ser - is the modulus of concrete rupture; $\mathrm{k} \leq 1$ coefficient of influence of principal compressive stresses.

Shear cracks are frequently found in the relatively thin webs of box girders despite the fact that calculations according to Eq. (2) show sufficient safety margin. It was assumed in the SN 365-67 that prestressed concrete remain free of cracks if the prestressing forces are designed to prevent tensile stresses due to bending loads not taken attention of the many other effects on structures. The SN code provisions, for example, did not treat box girders in temperature change and torsional effects and many other effects which were neglected in design calculations.
It should be mentioned the following possible causes of web-shear cracking of prestressed concrete precast segmental bridge structures:

* continually changing combinations of high shear and flexural stresses which occur near the loads and reactions (including overloading);

${ }^{*}$ additional torsional stresses in the webs due to eccentrically applied live loads;

* high principal compressive stresses in the inclined sections due to external loads and prestressing force;

* insufficient initial prestressing and long-term losses in the tendons due to shrinkage and creep of concrete members or its joints as well as steel relaxation which results in reduced compressive stresses in the webs;

* temperature gradient stresses which occur in the structures due to seasonal and daily temperature changes;

* inadequate cross-section area or shape of members.

Sectional forces due to transverse bending, shear, and torsion. It is well known that traffic loading for bridges is quite complex due to varying length, weight, and spacing of vehicles as well as its longitudinal and transverse placement on bridges. The response of structures to these loads are also random variables. The intensity of design live loads on bridges depends on code requirements in various countries.

In the cross-section of the bridge box girders subjected to service dead and live loads, the sectional forces (bending and torsional moments, shear and normal forces) occur (Fig. 4, a). The combined flexure, shear, and torsion forces induce in the concrete the normal stresses $\sigma_{x}$ due to prestress and external loads, vertical stresses $\sigma_{y}$ due to vertical component of the prestressing forces as well as external concentrated loads, the shear stress $\tau_{q}$ due to bending in the longitudinal direction, and the shear stress $\tau_{i}$ due to torsion of the cross-section of the beam. The horizontal and vertical stresses $\sigma_{x}$ and $\sigma_{y}$ as well as shearing stresses due to force $Q$ and torsional moment $T$ are acting on the critical element

(Fig. 4, c). 

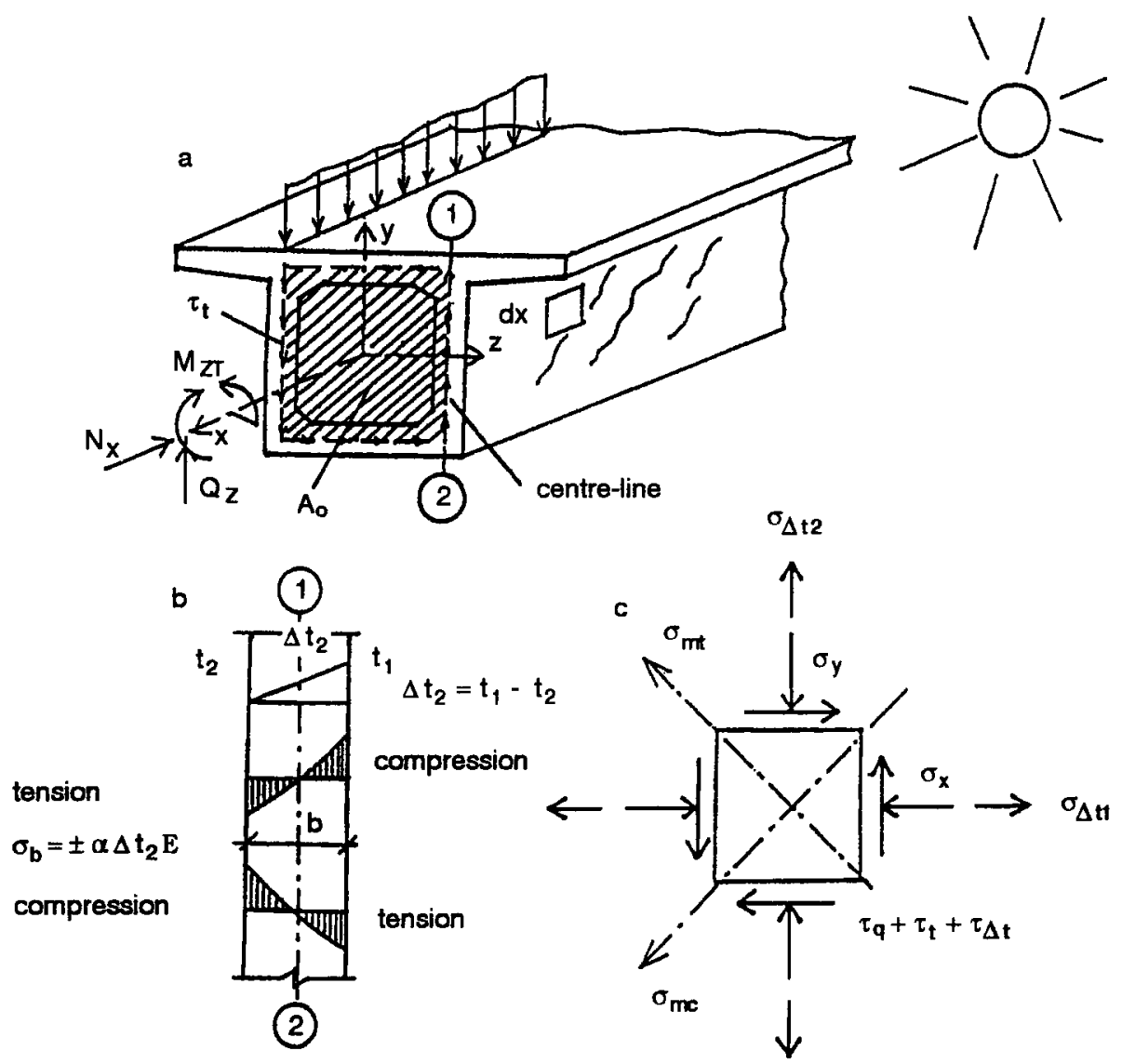

Fig. 4. Sectional forces acting on the cross-section of box girder (a), temperature stresses across the section of the web (b), and critical element (c)

The shear crack occurs when the principal tensile stresses due to the action of $\sigma_{\triangleright} \sigma_{p} \tau_{q}$, and $\tau_{t}$ will exceed the tensile strength of the concrete.

The torsion produces a shear flow around the perimeter of box cross-section. This shear flow is related to the applied torque by the equilibrium equation

$$
T=2 A_{o} \tau_{i} b
$$

which can be rearranged in the form:

$$
\tau_{t}=T / 2 A_{o} b,
$$

where $A_{o}$ is the area enclosed by the shear flow path.

Then, the shear stresses due to bending and torsion are given by:

$$
\tau=\tau_{q}+\tau_{t}=Q S / I b+T / 2 A_{o}
$$

The influence of additional torsional stresses on the resistance to shear cracking of bridge structures was introduced in the design code SN 2.05.03-84 later (from 1984).
Biaxial behaviour of concrete in tension. It can be seen from Eq. (2) that the structural member will not crack in inclined section if higher compressive stresses are applied. But it is true only up to a certain limit. Under biaxial tension-compression, the tensile strength of concrete $\left(\sigma_{m t}\right)$ decreases almost approximately linearly as the applied compressive stress $\left(\sigma_{m c}\right)$ is increased (Fig. 5, straight line 1). Thereby the excessive prestressing increases the principal compressive stress and as a result reduces the tensile strength of concrete.

In recent bridge code specifications, stricter requirements concerning influence of principal compressive stresses on the concrete tensile strength are presented .

Prestress losses. In precast segmental bridge girders the total prestress losses:

$$
\sigma_{l o s s}=\sigma_{s h}+\sigma_{c r}+\sigma_{r}+\sigma_{\dot{p}}
$$

where $\sigma_{s h}$ - loss due to concrete shrinkage; $\sigma_{c r}$ - loss due to creep of concrete; $\sigma_{r}$ - loss due to relaxation of 


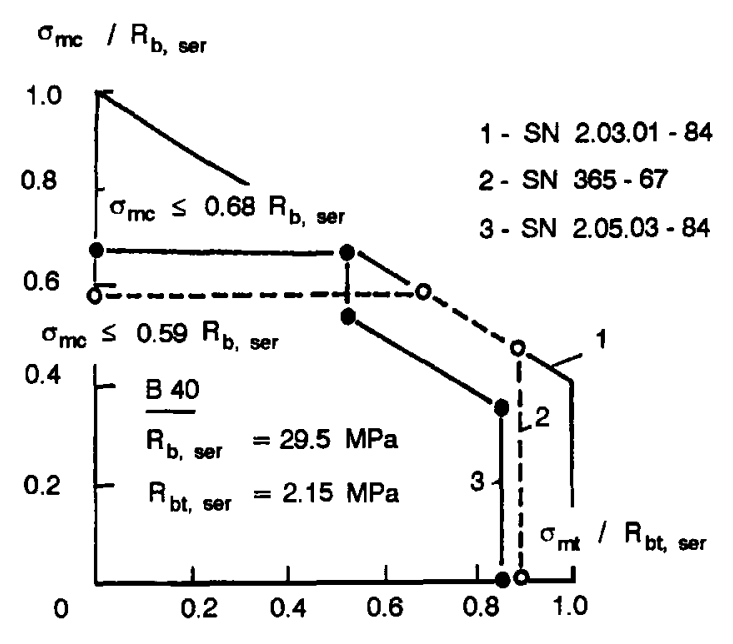

Fig. 5. Failure criteria for concrete B40 in plane stress state by various codes

prestressing steel; $\sigma_{j}$ - loss due to creep and shrinkage of concrete or polymer joints between precast segments.

The above prestress loss components $\sigma_{s h}, \sigma_{c r}$, and $\sigma_{r}$ can be determined by specified equations given in many codes but they are outside the scope of this report. It is necessary only to stress here that the reduction in prestressing force caused by shrinkage and creep of concrete may be of major importance. The codes normally give the most conservative results. In modern bridge structures the creep and shrinkage analysis have to be made taking in to consideration the continually changing time dependent loading, temperature, and moisture conditions.

Concrete match-cast or polymer grouted joints are obviously of the utmost importance in connecting the precast segments of bridge girders. As well as the girders, the joints between segments should be capable of transferring compressive, shearing, and torsional forces.

According to the current code SN 2.05.03 - 84 the loss of prestressing in post-tensioned structures due to deformation of precast segmental joints:

$$
\sigma_{j}=n \Delta E_{s} / l,
$$

where $n$ - number of joints; $\Delta$ - deformation of joint (for concrete match-cast joints $\Delta \boldsymbol{\nu}=0.3 \mathrm{~mm}$, for polymer grouted $\Delta l=0) ; E_{s}$ - modulus of elasticity of steel; $l$ - length of prestressed tendon.

Our own investigations show [4], that the polymer grouted joints in segmental structures are more deformable than those of adjacent concrete.
Creep deformations of the glued bonds under long term or cyclic compression are influenced by the degree of stress, thickness of the glue joint as well as composition and age of the glue. On the basis of these results the following formula for the loss of prestressing due to creep in polymer grouted joints was proposed:

$$
\sigma_{j}=n d_{k} \sigma_{b} \beta C_{b}(t) E_{s} / l,
$$

where $d_{k}$ - thickness of the joint; $\sigma_{b}$ - compressive stress in concrete at centroid of prestressed tendon; $C_{b}(t)$ - creep per unity of concrete stress at moment $t$.

Creep increase factor for segmental structures based on investigation [4]:

$$
\beta=1+0.28 d_{k} \sigma_{b} / R_{b, s e r}
$$

The erection quality of joints can be also of great importance for deformability of segmental structures. For concrete joints high strength cast-in-place concrete of the same strength as that of adjacent precast segments has to be used. It was found [4] to be very difficult to achieve uniformly good workmanship especially in all relatively thin vertical joints of box girder webs. Due to excessive variation in concrete or resin thickness and not complete filling of the joint the stress concentrations as well as additional prestressing losses can occur.

Thermal effects. Thermal effects on bridge structures are manifested by seasonal or daily temperature changes. Seasonal temperature variations are reflected basically on the longitudinal deformations of a bridge and influence the design of bearings and expansion joints as well as the structures where thermally induced movements are restrained. Results of measured daily monitoring of temperatures in box girders are presented in Fig. 6 [4]. It can be seen that daily temperature changes cause the thermal gradient within the bridge cross-section. The temperature gradients occur between top and bottom slabs, outside and inside of box girder sections, exterior and interior beams. The magnitude of temperature gradient depends on the amount of solar radiation (location of a bridge), ambient temperature, wind fluctuations, section shape, surface characteristics. Radiation reaching and penetrating the deck surfacing is converted to heat. The upper elements have higher temperatures than the bottom ones. The extent of 
heating of box girder deck slab depends on the surface type (material, colour, thickness).

The temperature gradients in a bridge of statically indeterminate concrete superstructure (continuous beams, frames, box cross-sections) will result in rotation distortions in longitudinal and transverse direction producing stresses. It is known that the thermal stresses and deformations have damaged some post-tensioned box girder bridges [6].

Nevertheless, a wide variety of weather conditions in various countries, the similar vertical non-linear temperature distribution produced by heating under the sun and cooling during the night were obtained (Fig. 7). The temperature distribution within a cross-section must vary with time. Thermal gradients influenced by local meteorology conditions and based on long-term observations in code recommendations of several countries are presented in Fig.7.

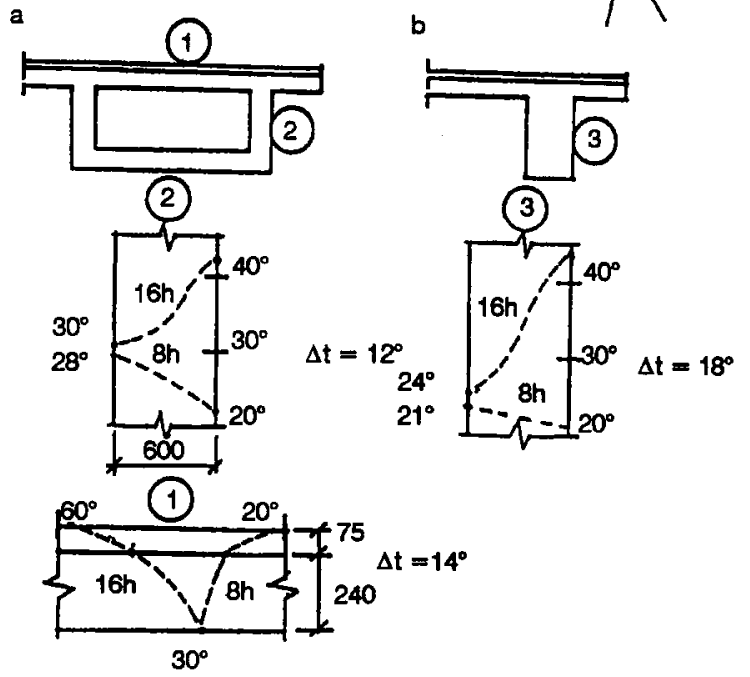

Fig. 6. Temperature gradient in bridge decks: a - box beam; b - T-beam

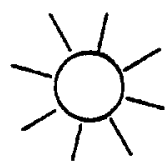

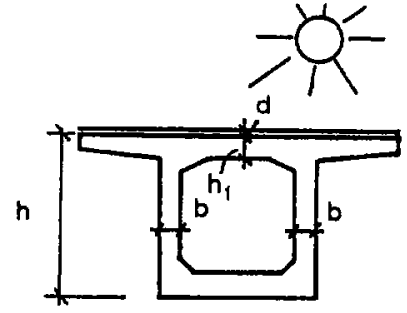
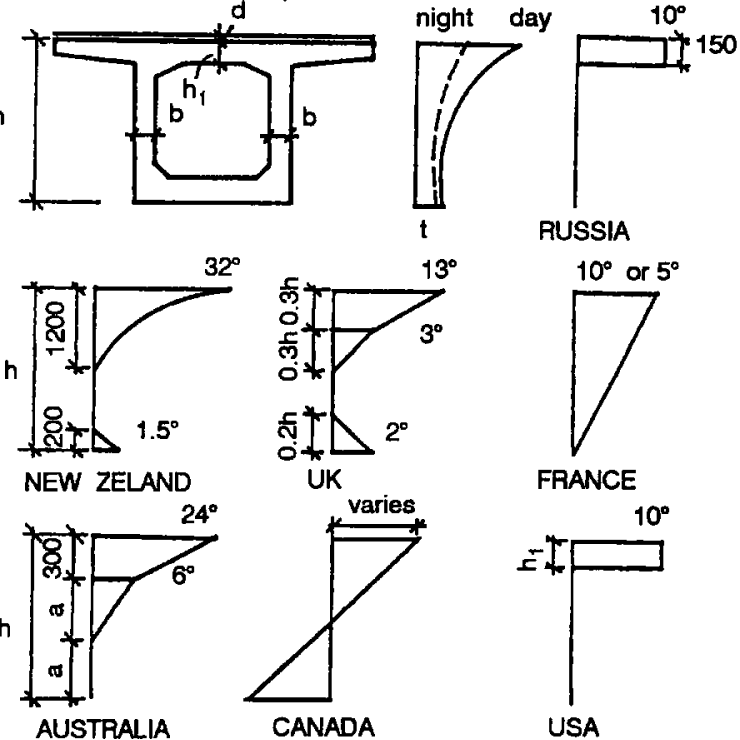

AUSTRALIA

In statically indeterminate structures, the restrained thermal deformations cause additional restraint moments, shear, and axial forces. In case of three-span continuous beam, for example, the beam try to arch upward because the deck slab is heated more quickly than the bottom one (Fig. 8).

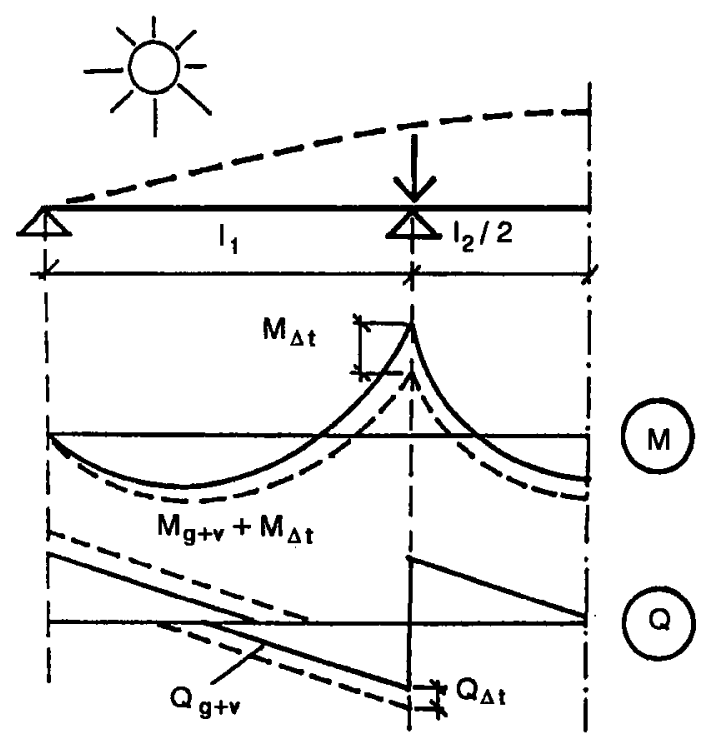

Fig. 8. Moments $\mathrm{M}$ and shear forces $\mathrm{Q}$ caused by thermal gradient in three-span bridge deck 
Thermal expansion or contraction, as well as bowing of beam is prevented by reactions at the supports which cause stresses $\sigma_{\Delta t 1}$ and $\tau_{\Delta t}$ (Fig. 4, c) in the vertical cross- section of the beam. The stresses in cross-section are calculated by assuming that the thermal deformations first occur and then the reactions are applied to bring the beam back to its original length. Temperature induced stresses in the cross-section of bridge superstructures from Ref. [8] may be as high as $2 \mathrm{MPa}$. It seems that there is a significant tension in the bottom zone of cross- section as a consequence of the thermal action. The temperature related stresses are often of the same magnitude as the service load stresses.

The bending moment $M_{\Delta}$ required to restrain the beam from bowing:

$$
M_{\Delta t}=\Delta t \alpha E I / h .
$$

This results in a shearing force $Q_{\Delta}$ and shearing stress $\tau_{\Delta}:$

$$
\tau_{\Delta:}=\Delta t \alpha E I / l_{1}(S / 2 I b),
$$

where $\alpha$ - coefficient of thermal expansion of concrete; $E$ - Young's modulus of concrete; $\Delta t$ temperature change.

In transverse direction of a bridge, the box sections are also indeterminate structures and the thermal stresses occur when the cross-section is heated on one side by the sun (Fig. 4, b). This is applicable to the external beams of a bridge. Opposite temperature gradients can also occur due to rapid cooling of exposed concrete surface. The outside of the web is subjected to an alternative higher and lower temperatures. The webs of box girders are restrained in the deck and bottom slabs. It can be assumed that webs are free for length changes and fully restrained against bowing. Due to restraint bowing, the colder surface is subjected to tensile, and the warmer surface to the compressive stresses. The web is subjected to an alternative compression-tension stresses $\sigma_{\Delta t 2}$ (Fig. $4, b$ and $c$ ).

The bowing moment depends on the depth of the web:

$$
M_{\Delta t w}=\Delta t_{2} \alpha E I_{w} / b .
$$

Finally, it its possible to conclude that thermal gradient and stresses occur in the indeterminate superstructures and are reflected on the stresses $\sigma_{x} \sigma_{y}$, and $\tau$ in Eq. (1), affecting the cracking resistance of box girder structures. Creep of concrete has a considerable influence on the thermal stresses and deflections of heated elements.

Web dimension parameters. It is known that in prestressed concrete beams web-shear cracking usually occurs with thin webs. Statistical studies were made to evaluate some geometric characteristics of prestressed concrete of box cross-section bridge superstructures, leading to an assessment of shear cracking resistance of webs.

In order to analyse the web dimensions three parameters were determined: girder depth $\left(h_{1}\right)$, pier to midspan girder depth ratio $\left(h_{2} / h_{1}\right)$, and the total web area to the bridge width ratio $\left(h_{l} b_{w} / b\right)$. The analysis was made on the results of an extensive survey of segmental precast box girder bridges built until 1982 in the United States [2], France [7], and Lithuania. Statistical studies were conducted to determine the correlation of parameters. A good correlation between constant girder depth as well as pier-to-midspan-depth ratios and span length for all investigated bridges are found. It is important to stress that the parameter $h_{l} b_{w} / b$ for bridges built in Lithuania is lower than that for US and France bridges especially for long span bridges. This indicates that for the same span length the Lithuanian bridges are of thinner webs.

\section{Conclusions}

In many post-tensioned concrete bridges built in Lithuania until 1982 an intensive shear cracking of box girders is observed. It occurs when the principal tensile stresses due to combination of service loads and restraint forces exceed the tensile strength of concrete. The inclined cracks in the webs change the behaviour of the original monolithic structure and a new analysis has to be developed for existing cracked concrete structures.

Prestressed concrete segmental box girder superstructures are generally subjected to the complex action due to bending, shear, torsion, thermal, creep, shrinkage, plastic yielding, interface slipping effects which make the theoretical prediction and interpretation of stress-strain state extremely difficult. It is necessary therefore to provide these 
factors, many of them being time-dependent, in the design of prestressed concrete structures. Actually not all of them are introduced in the design codes.

The significant stresses occur over the depth of a superstructure members due to temperature gradients. It is important to perform the in-situ measurements to determine the magnitude and distributions of temperatures at various moments in the bridge superstructures. The orientation of the bridges relative to the north-south axis has to be taken into account.

It seems that a sufficient cracking resistance of existing bridge superstructures can be achieved by increasing the dimensions of cross-section of box girder webs.

This investigation is the first attempt to analyse the causes of diagonal cracking in prestressed concrete bridge box girders. The next step has to be made to assess the conformity of existing bridges in Lithuania to EC code requirements as well as to envisage the field and laboratory investigations in order to collect necessary information on the behaviour and future strengthening of the cracked structures.

\section{References}

1. Schlaich J., Scheet H. Concrete box-girder bridges. Zurich, Switzerland: Publishers IABSE, AIPC, 1982, $108 \mathrm{p}$.

2. Kulka F., Thoman S.J. Feasibility study of standard sections for segmental prestressed concrete box girder bridges // Journal PCI, 1983, Vol. 28, No 5, p. 54-77.

3. Malett G.P. Repair of concrete bridges. London: TRL, 1994, $194 \mathrm{p}$.

4. Kamaitis Z. Gelžbetoniniu tilty būklè ir jos vertinimas. Vilnius: Technika, 1995, 182 p.

5. New in design of concrete and reinforced concrete structures. Moscow: 1978, 208 p. (in Russian)

6. Podolny $\mathrm{W}$. The cause of cracking in post-tensioned concrete box girder bridges and retrofit procedures // Journal PCI, 1985, No 2, p. 82-139.
7. La technique francaise du beton precontraint // IX congress international de la FIP. Stockholm: 1982, p. 22-77.

8. Potgieter I.C., Camble W.L. Nonlinear Temperature Distributions in Bridges at Different Locations in the US // PCI Journal, 1989, Vol. 34, No 4, p. 80-103.

Iteikta 19961114

\section{IŠ ANKSTO ITEMPTU GELŽBETONINIU TILTU DĖŽINIỤ PERDANGŲ İSTRIŽŲJŲ PJŪVIU PLEIŠĖJIMO PRIEŽASTYY}

\section{Z.Kamaitis}

\section{Santrauka}

Iš anksto įtemptose tiltų dèžinèse surenkamosiose perdangose pastebimas intensyvus vertikaliu sieneliy pleišejimas istrižuose pjūviuose. Intensyviau pleišēja perdangų kraštinès sijos. Plyšių atsivérimo plotis kartais siekia $1 \mathrm{~mm}$ ir daugiau. Plyšius ne visada galima apibūdinti vien tik atsivérimo pločiu. Dažnai plyšiu pločiai stabilizuojasi arba net susiaureja, bet ilgeja esami arba atsiranda nauji plyšiai.

Straipsnyje analizuojamos plyšių atsiradimo priežastys. Projektuojant déžines surenkamąsias perdangas nebuvo atsižvelgta i sukimo ir temperatūrines ịrąžas, galimus išankstinio itempimo nuostolius dèl klijuoty ar betoniniu siaurujų sandūru deformaciju, nepakankamai ịvertinta svarbiausiuju gniuždymo itempimy itaka. Lyginant su analogiškais tiltais JAV ir Prancūzijoje, Lietuvoje pastatyty tiltu déžiniu perdangu sienelès plonesnès. Šiuo metu mažai žinome apie iš anksto itemptos armatūros itempimy nuostolius del betono ir surenkamujy elementy sandūrų valkšnumo. Respublikoje netyrinèta paros temperatüros svyravimu įtaka statiškai nesprendžiamų sistemu ịrąžoms. Pasiūlyta metodika apskaičiuoti išankstinio itempimo nuostoliams dèl klijuotų sandūrų valkšnumo. Reikètų ištirti Lietuvos klimatiniy poveikiy itaką tiltụ perdangy konstrukcijoms.

Zenonas KAMArTIS. Doctor Habil, Professor. Director of International Studies Centre. Vilnius Gediminas Technical University, 11 Saulètekio Ave, 2040 Vilnius, Lithuania.

A graduate of Kaunas Politechnical Institute in 1958 (Civ Eng). Doctor's degree in 1968. Expert member of Lithuanian Academy of Sciences. Author and co-author of more than 150 publications, including 6 books. Research interests: concrete structures and bridges, materials, durability, monitoring, and refurbishment. 